\title{
Less Costlier and Emergency Options for Intubation during Coronavirus Disease Times
}

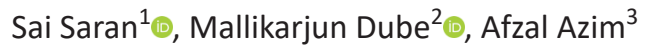 \\ Keywords: Aerosol-generating medical procedures, COVID-19, Emergency intubation, Endotracheal intubation. \\ Indian Journal of Critical Care Medicine (2021): 10.5005/jp-journals-10071-24049
}

To the Editor,

Aerosol-generating procedures (AGPs) pose a high risk of infection to healthcare workers ( $\mathrm{HCWs})$, especially during the recent coronavirus disease-2019 (COVID-19) pandemic. ${ }^{1}$ The risk of airborne spread is even higher with intubation in critically ill patients, as it involves close proximity to the airway. ${ }^{2-4}$ Various position statements from societies underline the necessary precautions required to minimize the infection to HCWs during intubation such as performing the procedure in a well-ventilated room (negative pressure isolation room with a minimum of 12 air changes per hour), with personal protective equipment geared in (goggles, face shield, water-resistant gown with hood, double layer of gloves, and N95 or its equivalent respirator). ${ }^{2-4}$ Apart from these, the guidelines suggest the use of video laryngoscopy and use of sedation and paralytics to facilitate intubation at a distance and avoid coughing during the procedure, respectively. The use of an intubation box can also be helpful but can hamper visualization of the airway (already impaired with goggles and face shield especially over the prescription glasses of the $\mathrm{HCW}$ ) and dexterity due to limited movement of hands inside the box. ${ }^{5}$

Video laryngoscopes are expensive and difficult to procure in rural and semi-urban hospitals such as primary and community health centers in low-middle income countries, and trained personnel to handle these devices are in shortage. During emergency situations and prior to the availability of diagnostic reports of severe acute respiratory syndrome coronavirus 2 (SARS-CoV-2) infection, it may not sometimes be possible to follow intubation protocols as suggested in guidelines even at tertiary care and referral centers. In these situations, in addition to protective gear such as N95 respirator, face shields and gloves, and under sedation and paralytics, we suggest intubation using an endotracheal tube with a partly inflated cuff with blocked distal end (with a cap or adapter or vacutainer, which matches the universal size of $15 \mathrm{~mm}$ diameter) as shown in
${ }^{1}$ Department of Critical Care Medicine, King George Medical University, Lucknow, Uttar Pradesh, India

${ }^{2,3}$ Department of Critical Care Medicine, Sanjay Gandhi Postgraduate Institute of Medical Sciences, Lucknow, Uttar Pradesh, India

Corresponding Author: Afzal Azim, Department of Critical Care Medicine, Sanjay Gandhi Postgraduate Institute of Medical Sciences, Lucknow, Uttar Pradesh, India, Phone: +91 8004904730, e-mail: draazim2002@gmail.com

How to cite this article: Saran S, Dube M, Azim A. Less Costlier and Emergency Options for Intubation during Coronavirus Disease Times. Indian J Crit Care Med 2021;25(12):1462-1463.

Source of support: Nil

Conflict of interest: None

Figures $1 \mathrm{~A}$ to $\mathrm{D}$. Blocking the distal end of the endotracheal tube will reduce chances of aerosol spill (blast of air) on the face of the intubator, especially with techniques like direct laryngoscopy, where the intubator is in close proximity to the airway. This is especially useful when there is no time for the muscle relaxant to act or failure of muscle relaxant to act while adding to additional safety of the HCW. Once the intubation is done under vision, the $\mathrm{HCW}$ can come to a safe distance, remove the cap or adapter, and connect the endotracheal tube to the ventilator with heat moisture exchange filters (HMEF) or bacterial-viral filters (BVF) at the end of endotracheal tube and at expiratory port of the ventilator. There might be difficulties in the removal of the blocker, which needs to be rehearsed earlier, especially if snuggly fitting. Therefore, a surgical blade along with $15-\mathrm{mm}$ connector of the same size or one size lesser endotracheal tube needs to be kept ready, so that the tube can be cut and new connector can be inserted. After usage, these blockers should be kept in high concentration of disinfectant solution like 1-2\% sodium hypochlorite and disposed of for incineration.

() The Author(s). 2021 Open Access This article is distributed under the terms of the Creative Commons Attribution 4.0 International License (https://creativecommons. org/licenses/by-nc/4.0/), which permits unrestricted use, distribution, and non-commercial reproduction in any medium, provided you give appropriate credit to the original author(s) and the source, provide a link to the Creative Commons license, and indicate if changes were made. The Creative Commons Public Domain Dedication waiver (http://creativecommons.org/publicdomain/zero/1.0/) applies to the data made available in this article, unless otherwise stated. 

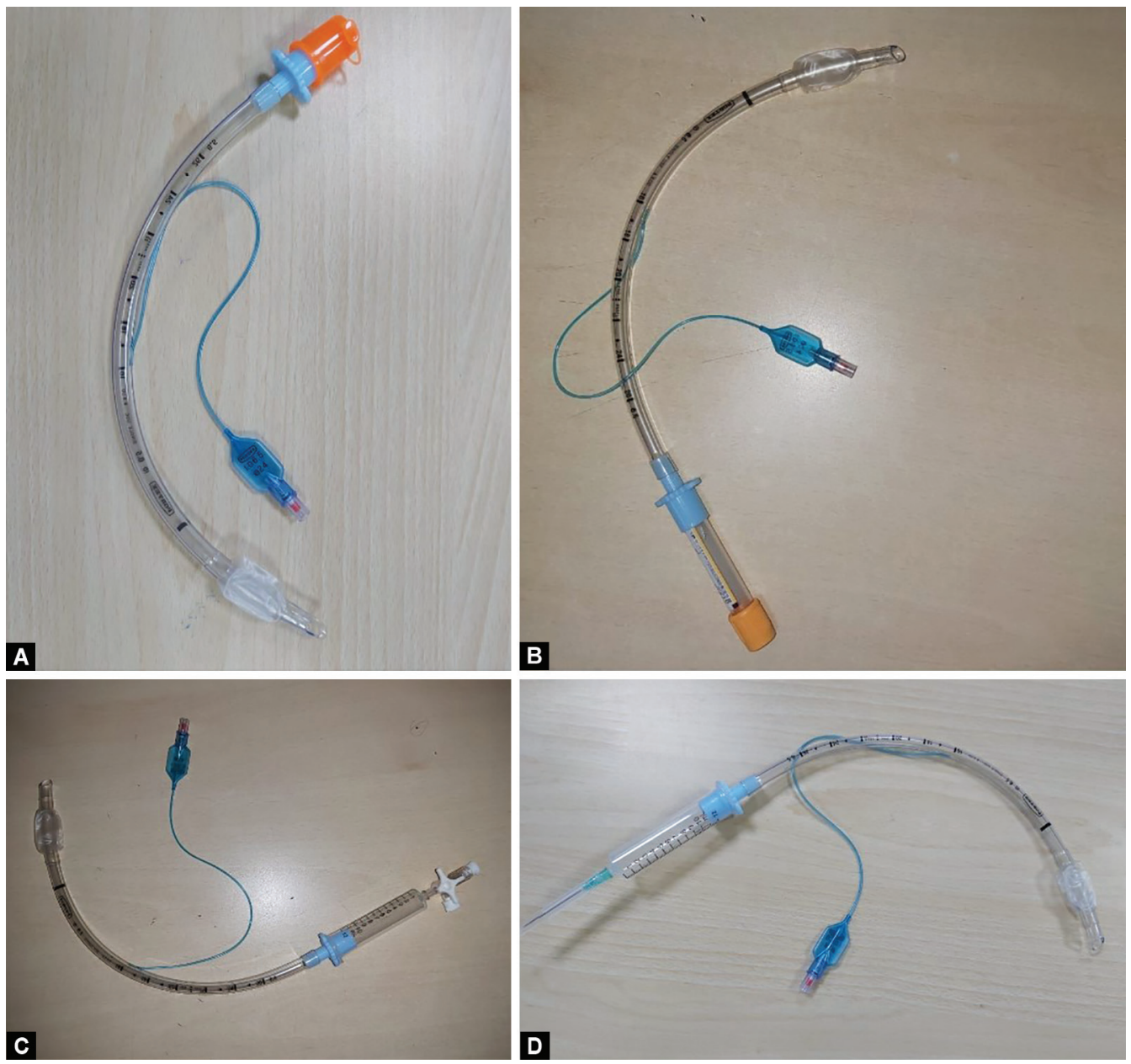

Figs 1 A to D: Various options to block the distal end of endotracheal tube. (A) With a cap; (B) With vacutainer; (C) 10-mL syringe plunger with a three way; (D) 10-mL syringe plunger

\section{OrCID}

Sai Saran (1) https://orcid.org/0000-0002-6181-8661

Mallikarjun Dube 으 https://orcid.org/0000-0003-0712-9563

\section{References}

1. Tran K, Cimon K, Severn M, Pessoa-Silva CL, Conly J. Aerosol generating procedures and risk of transmission of acute respiratory infections to healthcare workers: a systematic review. PLoS One 2012;7(4):e35797. DOI: 10.1371/journal.pone.0035797.

2. Orser BA. Recommendations for endotracheal intubation of COVID-19 patients. Anesth Analg 2020;130(5):1109-1110. DOI: 10.1213/ ANE.0000000000004803.
3. Rao B, Singh S, Chacko J, Mani R, Wattal C, Mehta Y, et al. Critical care for COVID-19 affected patients: position statement of the Indian Society of Critical Care Medicine. Indian J Crit Care Med 2020;24(4):222-241. DOI: 10.5005/jp-journals-10071-23395.

4. Malhotra N, Joshi M, Datta R, Bajwa SS, Mehdiratta L. Indian society of anaesthesiologists (ISA national) advisory and position statement regarding COVID-19. Indian J Anaesth 2020;64(4):259. DOI: 10.4103/ ija.IJA_288_20. Available from: http://www.ijaweb.org/text. asp?2020/64/4/259/281533.

5. Dalli J, Khan MF, Marsh B, Nolan K, Cahill RA. Evaluating intubation boxes for airway management. Br J Anaesth 2020;125(3):e293-e295. DOI: 10.1016/j.bja.2020.05.006. Available from: https://linkinghub. elsevier.com/retrieve/pii/S0007091220303482. 